\title{
THE ECONOMIC AND SOCIAL CONTEXT FOR THE CHANGES IN ACCIDENT COMPENSATION
}

\author{
Robert Stephens $^{*}$
}

The changes in ACC after 1980 cannot be separated from profound changes in the shape and direction of New Zealand's political economy. Responding initially to the inherited economic imbalances in the 1970s, after 1984 the governing Labour Party launched a major restructuring of the economy and state administration. This paper describes the theories and objectives behind that transformation, as well as the generally disappointing results for economic performance and social equity. Further erosion of confidence in the state and dedication to market-driven policies continued well into the 1990s under the National Party. This paper documents the major trends during this entire period for employment, productivity, social inequality, and poverty.

\section{INTRODUCTION}

Ever since its inception in 1973, the Accident Compensation Commission (ACC) has been both an administrative orphan, through its establishment as a quango rather than department of State, ${ }^{1}$ and a social outlier, based on social insurance principles rather than the tax-financed, flat-rate benefits of the existing social security system. ${ }^{2}$ However, the subsequent changes to ACC are integrally related to the wider political context that drove the economic and social changes faced by New Zealand during the last two decades of the twentieth century.

During the 1980s, the successive Ministers of Finance, Robert D Muldoon (National) and Roger Douglas (Labour) had polar views on the objectives of policy, the appropriate economic theory, the role of markets, and the effectiveness of fiscal and monetary policy in maintaining economic

* Robert Stephens, Senior Lecturer in Public Policy and Economics in the School of Government at Victoria University of Wellington.

1 John R Martin "Establishment of the Accident Compensation Commission 1973: Administrative Challenges" (2003) 34 VUWLR 249.

2 Margaret McClure "A Decade of Confusion: The Differing Directions of Social Security and Accident Compensation 1969-1979" (2003) 34 VUWLR 269. 
stability. The 1980s transformed the economic landscape, moving the economy from a heavily regulated and protected environment to an open economy with market forces determining resource allocation. ${ }^{3}$ The 1990 s witnessed an equally dramatic overhaul of the welfare state, moving from predominantly state funding and universal or categorical provision to a residualist and targeted welfare state with increased private funding and provision. ${ }^{4}$

While the majority of the papers in this volume trace the development of ACC, this article sets the economic and social scene and context for those changes. The reforms to ACC relate more to the underlying economic theories and views on human motivation of the reform era than to the intellectual origins of ACC. The ACC changes relate to attempts to reduce the level and scope of government by greater use of resource allocation via market mechanisms coupled with developments in the machinery of government and income maintenance arenas rather than the principles of social insurance. The economic theory and changing views on human motivation that underpinned the reforms represent the starting point for this article. The contrast between the two halves of the 1980s is made before some of the reform details are considered, while presenting some of the less than impressive economic and social outcomes from that period. ${ }^{5}$

\section{DIRECTIONS OF SOCIAL AND ECONOMIC CHANGE}

\section{A The End of the Golden Weather}

The immediate post-war period saw New Zealand enjoy a comparatively high standard of living, with increasing demand for agricultural production through preferential access to the United Kingdom market. Unemployment remained low through this period, assisted by a system of import licences and tariffs that enabled an embryonic manufacturing sector to develop, using international capital to finance investment in plant and machinery. Figure 1 shows the continuous prosperity through the 1960s, with high rates of economic growth, modest inflation and a very low level of unemployment. Figure 2 shows relatively small deficits on both the balance of payments on current account and the government budget. These deficits were used beneficially as they permitted capital inflow for net new investment to foster further economic growth.

3 Jane Kelsey The New Zealand Experiment: A World Model for Structural Adjustment? (Auckland University Press, Auckland, 1995).

4 Robert Stephens "Social Service" in Brian Silverstone, Alan Bollard and Ralph Lattimore (eds) A Study of Economic Reform: The Case of New Zealand (Elsevier, Amsterdam, 1996) 451.

5 For a more detailed analysis of the reforms, from a variety of philosophical perspectives, see Alan Bollard "New Zealand" in John Williamson (ed) The Political Economy of Policy Reform (Institute for International Economics, Washington DC, 1994) 1; Brian Easton The Commercialisation of New Zealand (Auckland University Press, Auckland, 1997); Lewis Evans, Arthur Grimes, Bryce Wilkinson and David Teece "Economic Reform in New Zealand 1984-95: The Pursuit of Efficiency" (1996) 34 Journal of Economic Literature 1856; Silverstone, Bollard and Lattimore, above. 
As a consequence, during the 1960 s New Zealand could afford a modest social security system and universal health care and education at minimal fiscal cost, and declining aggregate government expenditure (Figure 3). The social security system provided a flat-rate benefit as of right to those in contingent groups likely to be at risk of hardship. The reciprocal obligation to seek work was accepted by the majority of beneficiaries. As a consequence, people were on benefits due to factors beyond their control - poor health, old age or lack of effective macroeconomic demand.

These three Figures also demonstrate that New Zealand fared worse than most of its Organisation for Economic Cooperation and Development (OECD) compatriots during the 1970s. The combined impact of oil-price shocks, the initial impact of global restructuring, United Kingdom entry into the European Community plus the distortionary impact of the European Community's Common Agricultural Policy resulted in stagflation - low economic growth and rising inflation. However, internal policies within New Zealand exacerbated the impact. Import protection had resulted in a high exchange rate, and when combined with the resulting increased costs for farmers and exports of manufactured products, led to the introduction of Supplementary Minimum Prices for many agricultural products and export incentives for manufacturers. This attempt to offset the home market bias from import protection led to further price distortions within the New Zealand economy, and greater government expenditure.

Attempts to cure a significant balance of payments deficit by curbing internal demand resulted in low growth and increasing unemployment from the mid-1970s. Both the balance of payments deficit and the budget deficit allowed New Zealanders to live beyond their means (or consume more than they were able to produce). The result was increasing internal and external debt, and the interest on that debt fuelled growth in government spending, crowding out other government expenditures.

Thus New Zealand entered the 1980s with a seriously distorted economy, with low economic growth, high inflation and increasing fiscal pressures. The New Zealand Planning Council had argued "the fact that government revenue requirements have increased at a time when real take home pay was falling has made New Zealanders more conscious of the cost of public policy". ${ }^{6}$ The Planning Council accepted that economic growth would be less than 3 per cent per annum, and then argued that government expenditure needed to be contained to less than the Gross Domestic Product (GDP) growth rate, with the major recommendation being a reduction in the cost of National Superannuation. ${ }^{7}$

6 New Zealand Planning Council The Welfare State? Social Policy in the 1980s (New Zealand Planning Council, Wellington, 1979).

7 On ACC the Planning Council recommended that the Sickness and Invalids Benefits should be integrated with ACC, with a short-term earnings-related benefit for both groups and in the long-term a flat-rate social assistance benefit. Rehabilitation was to be uniform across both groups. 
As Table 1 indicates, the policy responses taken by successive governments could not have diverged more, and were totally contrary to the traditional philosophical premises of their political parties. As Prime Minister and Minister of Finance for the conservative, right-wing National Government between 1975 and 1984, Robert D Muldoon became increasingly interventionist, regulating markets, trade and investment decisions, and controlling inflation through a wage-price freeze. After a snap election in 1984, with no agreed detailed manifesto to pursue, the three Finance Ministers (Roger Douglas, Richard Prebble and David Caygill) of the traditionally left-leaning Labour Government used a post-election constitutional crisis emanating from a run on foreign exchange to implement a range of market-based policies with seemingly limited concern for vertical equity.

TABLE 1: CONTRASTING POLICY INSTRUMENTS AND OBJECTIVES

\begin{tabular}{|c|c|c|}
\hline Policy & Muldoon 1975-84 & Lange/Douglas 1984-1990 \\
\hline Markets & $\begin{array}{l}\text { Regulate, wage/price freeze } \\
\text { for macro stability }\end{array}$ & $\begin{array}{l}\text { Deregulation, liberalisation } \\
\text { for efficiency of markets }\end{array}$ \\
\hline Government business entities & $\begin{array}{l}\text { Ministerial control, political } \\
\text { and social objectives }\end{array}$ & $\begin{array}{l}\text { Independence, commercial } \\
\text { criteria, internal efficiency }\end{array}$ \\
\hline Exchange Rate & $\begin{array}{l}\text { Fixed, balance of payments } \\
\text { deficit }\end{array}$ & $\begin{array}{l}\text { Devaluation, floating, but } \\
\text { overshooting }\end{array}$ \\
\hline International trade & $\begin{array}{l}\text { Protection, control capital } \\
\text { flows, offset home market } \\
\text { bias }\end{array}$ & $\begin{array}{l}\text { Removal of tariffs, free capital } \\
\text { flows, "the level playing field" }\end{array}$ \\
\hline Fiscal policy & $\begin{array}{l}\text { Keynesian expansion, deficit, } \\
\text { growth GDP }\end{array}$ & $\begin{array}{l}\text { Overcome deficit by tax } \\
\text { revenue, privatisation }\end{array}$ \\
\hline Monetary policy & $\begin{array}{l}\text { Conflict with fiscal, controls } \\
\text { on interest rates, lending }\end{array}$ & $\begin{array}{l}\text { Dominant, interest rates to } \\
\text { control inflation }\end{array}$ \\
\hline Tax & $\begin{array}{l}\text { Reliance on income tax, high } \\
\text { rates but loopholes }\end{array}$ & $\begin{array}{l}\text { Base broadening, lower top } \\
\text { rates, shift to indirect tax }\end{array}$ \\
\hline Social policy & $\begin{array}{l}\text { Universal, generous pension, } \\
\text { tax expenditures }\end{array}$ & $\begin{array}{l}\text { Incentives, targeting with fees, } \\
\text { family assistance }\end{array}$ \\
\hline Agriculture & $\begin{array}{l}\text { Supplementary minimum } \\
\text { prices, monopoly seller }\end{array}$ & $\begin{array}{l}\text { Free markets, producer board } \\
\text { monopoly reduced }\end{array}$ \\
\hline Government organisation & $\begin{array}{l}\text { Large departments, mixed } \\
\text { functions, input budgeting }\end{array}$ & $\begin{array}{l}\text { Separation into operations } \\
\text { policy, funding, output control }\end{array}$ \\
\hline
\end{tabular}




\section{B The Muldoon Era}

Faced with higher oil prices, slow growth, rising unemployment and increasing inflation, plus a distrust in the power of markets to reallocate resources in the face of global change, Muldoon was led to the development of the government-backed growth strategy projects (Think Big) revolving around intensive use of energy. While some projects were designed to reduce the dependency upon oil, the impact of importing the necessary technology and equipment had a negative impact on the balance of payments. Treasury calculations showed that the projects were only profitable if the real price of oil continued to increase dramatically. However, the subsequent decline in the oil price resulted in the government having to meet contractual obligations to the companies involved, further exacerbating a budget deficit situation (Figure 2). ${ }^{8}$

Throughout the 1970s and early 1980s, macroeconomic policy had been contradictory, with expansionary fiscal policy offset by tight monetary policy, combined with a three-year election cycle of boom and restraint. There was also a micro-economic aspect to this public choice perspective on policy, with policies such as the generous National Superannuation (paid from age 60) and the growth strategy projects designed to capture votes of special interest groups or key electorates. The policy focus was one of strong regulation (though many of the regulations were never enforced), with price controls on many key products, strict criteria for business entry, quotas and licences for imports, direct control over the money supply by reserve requirements for the banks and extensive occupational licensing.

This regulatory approach reaches its zenith in 1982 with the introduction of a comprehensive wage-price freeze on most prices, wages, salaries, directors' fees and interest rates. The reduction in consumer price inflation to 3.5 per cent in $1984^{9}$ (Figure 1) showed that the policy was a partial success, but the reverberation in inflation in 1985 shows the arbitrary nature of that success. Moreover, economic growth only averaged 2.2 per cent per annum over this period.

The freeze also came at the cost of a seriously distorted economy through developments such as fringe benefits as a significant part of some wage packets; the growth of fringe financial institutions to provide mortgage finance as the controls on bank mortgage lending rates led those institutions to withdraw their services; and differential cost increases impacted unevenly on firm profitability. Only international trade showed some signs of liberalisation, with seemingly reluctant moves to switch from import quotas to tariffs along with the development of a full free-trade agreement with Australia (Closer Economic Relations - CER). There was a significant rise in government expenditure, especially social security expenditure, due to the generous pension scheme (Figure 3) and the emergence of unemployment (Figure 1). Tax cuts in 1979 and 1982 offset the impact of

8 Paul Dalziel and Ralph Lattimore The New Zealand Macroeconomy: A Briefing on the Reforms (3 ed, Oxford University Press, Auckland, 1999).

9 Inflation measured by the GDP deflator fell from 15.6 per cent in 1982 to 8.0 per cent in 1984 
fiscal drag on wage packets, but failed to reduce disincentive and tax avoidance effects of high marginal tax rates of up to 66 per cent, and did not attempt to address the significant budget deficit of up to 20 per cent of government expenditure or 6-8 per cent of GDP (Figure 2).

\section{The 1984-1990 Era of Reform}

This period has to be initially seen as a reaction to the regulatory stance of the Muldoon era, and its poor economic outcomes, but quickly became a coherent policy direction when the objectives of reforming Ministers coincided with the economic theory and policy directions of the Treasury. While issues of economic efficiency always dominated the agenda, there are several caveats to that broad statement: first, during the period there was a change from allocative efficiency (ensuring that the nation is producing the right kinds of goods and services for its degree of comparative advantage and relative cost structure) to internal or managerial efficiency (maximising output within an organisation for its given inputs).

Second, the issue of horizontal equity ${ }^{10}$ - treating equals equally or "the level playing field" reinforced the allocative efficiency objectives. The view that government should be neutral in regard to resource allocation also meant that the income distribution and profit levels should be determined by market forces, modified by tax rates, rather than degree of government assistance, patronage or protection.

Third, in the first blush of the reforms, vertical equity and social justice concerns were considered, even if later abandoned for the benefit principle or user-pays philosophy. For high income earners, the broadening of the base of the personal income tax system possibly more than offset the initial reduction in the top take rate from 66 per cent to 48 per cent; the targeted family support tax credit for low income workers increased real take-home pay at the lower end of the income distribution; an affluence-test for the generous universal pension scheme was introduced; and increased health and education expenditures appeared in the first two Labour Budgets.

The economic theory underpinning the reforms has several inter-related strands, first presented in Treasury's (1984) Briefing to the Incoming Minister, Economic Management. ${ }^{11}$ The basic starting

10 As Musgrave in Richard Musgrave "ET, OT and SBT" (1976) 6 Journal of Public Economics 3-16, has pointed out, without horizontal equity, any attempt at achieving vertical equity is a random lottery. While tax and other changes reduced the nominal degree of income redistribution, the actual change in the redistributive impact of government was possibly far less, as many of the tax and other privileges applied to a proportion of those on higher incomes.

11 Both New Zealand Treasury Economic Management: Briefing to the Incoming Minister (Government Printer, Wellington, 1984) and Reserve Bank of New Zealand Post Election Paper to the Minister of Finance on the Areas of Responsibility of the Reserve Bank (RBNZ, Wellington, 1984) were critically reviewed by Zanetti and others in Giovanni Zanetti "Opening the Books: A Review Article" (1984) 18 New Zealand Economics Papers 13-30. The implicit predictions of the reviewers, especially on the macroeconomic side, were probably closer to the actual outcome than those of the Treasury (and Reserve Bank). 
block is the efficiency of markets hypothesis: that unfettered markets will speedily adjust to changing economic circumstances, ensuring full employment of resources as well as their efficient use. Distributional issues should not be directly addressed as that leads to disincentive effects. The economic growth resulting from market allocation will ensure a higher standard of living for all, with the trickle-down effect looking after the least well-off.

At the macro-economic level, the main theoretical framework was based on mainstream new classical macroeconomics, including rational expectations and the rejection of any trade-off between unemployment and inflation. Supply-side economics, with increasing emphasis on the role of economic incentives, became influential, especially in relation to the tax and benefit systems. Monetary policy, operated via varying interest-rates through control over the money supply, targeted inflation as the sole objective of policy. This inflation target later became enshrined in the Reserve Bank Act 1989, creating an independent Reserve Bank with annual rate of inflation target of zero to 2 percent. Fiscal policy was relegated to ensuring budgetary balance over a business cycle combined with minimal levels of debt. The Fiscal Responsibility Act 1994 gave legislative status to this objective, and this Act now places an effective constraint on government in relation to changing the magnitude of future tax and expenditure decisions.

The micro-economic theory was more radical. It combined developments in public choice, that saw the majority of government decisions as appeasing special interest groups for their political votes rather than to offset market failures; the economics of internal organisational behaviour, based on principal-agent theory, that demonstrated the incentive and monitoring problems within public sector organisations; and use of transaction cost and contestability theories that argued the need for only light-handed regulation to achieve efficient market-based outcomes via competition. ${ }^{12}$

\section{The Reform Details}

As the list below indicates, the economic reforms were widespread, affecting virtually every sector of the economy, and were implemented quickly without regard to the interdependencies between the reforms. The major reforms included:

- Devaluation of the exchange rate by 20 per cent in 1984 , to overcome the persistent balance of payments deficit by encouraging growth in value-added export industries. The exchange rate was floated in 1985 to stop the constraint on economic growth from an overvalued fixed exchange rate.

- Lifting the wage-price freeze, in order to provide the correct price signals for manufacturers, consumers and retailers.

12 Brian Silverstone, Alan Bollard and Ralph Lattimore (eds) A Study of Economic Reform: The Case of New Zealand (Elsevier, Amsterdam, 1996). 
- Removal of subsidies to business, and industrial deregulation. Arbitrary restrictions on entry and exit of firms and occupations were taken away. The objective was to achieve the neutrality of government in relation to private sector decisions and to ensure the benefits of competition through greater contestability of markets, which was especially important for the corporatisation/privatisation process.

- Corporatisation and privatisation of government trading departments. The objective of corporatisation was to increase both allocative and managerial efficiency: by the removal of ministerial control over decision-making and the development of commercial or profit criteria; by relating prices to costs of production, downstream industries faced appropriate price signals; and freedom of new entry would control monopoly behaviour. Privatisation was designed to permit capital market pressures to increase productive efficiency as well as reduce the size of the public debt. ${ }^{13}$

- Tax reform. The objectives were to increase government revenue, to make the tax system simpler, increase horizontal equity and reduce labour market disincentive effects. The top tax rate was cut from 66 per cent to 33 per cent, the tax base broadened, greater reliance was placed on indirect taxes through the introduction of a comprehensive, single-rate value-added tax, the Goods and Services Tax (GST) and greater tax assistance to low income families.

- $\quad$ Reform of the monetary and financial system. Monetary policy altered from direct control over the money supply to inflation targeting, the financial sector was deregulated, with relaxation of controls on entry into the financial sector and on bank lending, as well as permitting international capital flows.

- Removal of import protection. High and varied levels of effective rates of protection through import licenses were switched to tariff equivalents, with a timetable for reducing the average level of protection and making it more neutral between sectors - the level playing field - to improve allocative efficiency.

- Reform of public administration, with public servants becoming explicit agents for their minister, and the separation of policy advice from implementation and funding from provision.

- Under Labour, social policy reform was confused, resulting in the proliferation of Task Forces. However, there was a definite trend towards targeting rather than universality, greater use of household expenditures and private provision of services, resulting in the

13 While the sale of assets can be used to retire public debt, and thus future interest on debt, there are two offsetting factors. First, future dividends and profits from these assets will disappear, reducing future government revenue. Second, during the late 1980s, as the government budget was still in deficit, effectively asset sales allowed the government to maintain expenditure levels rather than retire debt. 
development of a user-pays philosophy, and a belief that the growth in beneficiary numbers was due to incorrect incentives in the benefit system.

\section{E Economic and Social Outcomes}

The outcomes of the reform process were disappointing. Figure 1 highlights the low or negative economic growth during the period and rising unemployment, though inflationary pressures were brought under control by the end of the decade. ${ }^{14}$ Both the balance of payments and budget deficits were reduced (Figure 2). ${ }^{15}$ At the macroeconomic level, the major problem was exchange rate overshooting, partly a consequence of incorrect sequencing of the reforms and partly through an overemphasis on the control of inflation.

Raising interest-rates through control of the supply of money had two inter-related effects in a small, open economy with no controls on capital flows. First, there is the direct effect of higher interest-rates on the domestic economy, especially investment activity. Second, higher interest-rates (relative to the rest of the world) lead to capital inflows, and raise the exchange rate above its equilibrium trade level: the higher exchange rate both lowers the price of import and export goods and services within New Zealand (achieving the inflation target) and reduces cost-push inflation via the lower level of internal demand. The reduction in aggregate demand was exacerbated by the substantial resource reallocation flowing out from the previously protected industries and the improvements in internal efficiency from the corporatised industries. But the overvalued exchange rate meant that there were few new growth industries to absorb the released labour.

After the 1987 stock market crash, ${ }^{16}$ the Labour Government was heavily divided on the direction of social and tax policy. One group wanted to apply the economic theory to social policy and substantially reduce the role of the state in education and health, with user pays, incentive effects and targeting. Another group wanted traditional social justice concerns to dominate. This split in Labour ensured its defeat in the 1990 election. But only after fees for tertiary education and

14 The high inflation of 1987 is partly due to the introduction of GST and that added roughly 7 per cent to the overall price level. GST did not lead to an inflationary spiral, as the trade unions accepted the simultaneous introduction of lower personal income tax rates as compensation. Nevertheless, the net tax burden for all bar the top 10 per cent of earners rose, Robert Stephens "Social Services" in Silverstone, Bollard and Lattimore, above, 451 .

15 Figure 2 shows a budget surplus (Table 2 basis) from 1988. Revenue from asset sales was (incorrectly) placed as operating revenue rather than as a capital transaction. Using accrual accounting, a true budget surplus (operating) only occurred from 1993.

16 New Zealand was probably hit most heavily by the November 1987 stock market crash. Banks, freed from direct control of their lending by the Reserve Bank, had overextended their lending to companies with substantial paper, but not real asset backing. Financial preservation of the banks required them to foreclose on several significant corporate entities, exacerbating the length of the recession. 
pharmaceuticals had been introduced, local control of schools had been imposed, health services reformed and devolved and plans for a single social security benefit unveiled.

\section{F The Legacy of National Governments, 1990-99}

In 1990, National campaigned on the slogan of a "Decent Society", implying that they would reverse Labour's welfare charges and offset the increase in income inequality. However, the first policy initiative was an attack on the fundamental principles of the welfare state, with a shift in philosophy from "participation and belonging to the community" to a "modest safety net" based on individual and family responsibility for well-being rather than community responsibility undertaken through the apparatus of the State. ${ }^{17}$

The general direction of economic management was maintained, with continuation of monetary policy to maintain the strict inflationary target, irrespective of the impact on other macroeconomic variables, privatisation and deregulation policies. The theories of efficiency of markets, contracting, managerialism and transaction costs were also applied to the welfare state with the introduction of quasi markets, or managed competition in health care, social service delivery and education. ${ }^{18}$ The separation of funding from service provision and delivery allowed private providers to compete with public hospitals, schools and other previously government controlled enterprises for contracts to provide pre-specified outputs. The aim was to increase productive efficiency, increase the responsiveness of service providers to client needs and give clients greater choice of service provider.

The major social policy changes were that social security benefits were cut by an average of 12 per cent in nominal terms; entitlement rules for benefits tightened; the health service reorganised with funder-provider splits coupled with targeted charges for services; a change in housing assistance from income-related state housing rentals to market rentals and a targeted housing supplement available for all forms of accommodation; increased tertiary student fees plus a switch from student grants to an income-contingent loan; a reduction in the universality of accident compensation and a change in the funding and organisation of the voluntary welfare sector. Grander, more integrated and targeted designs on the welfare state were planned with targeting of all social services, using Smart Card technology, so that "the top third of all income earners can be

17 The stated justification for this gestalt switch in approach was a small financial crisis in the corporatised Bank of New Zealand that had overextended its lending prior to the 1987 Stock Market crash. A more viable explanation is that the incoming government found that the government accounts were in far poorer condition than portrayed, as Labour's then Minister of Finance (David Caygill) had brought tax revenue forward through the shortening of tax payment periods. The changed philosophical approach accorded with the views of the incoming Minister of Finance (Ruth Richardson).

18 Jonathan Boston (ed) The State Under Contract (Bridget Williams Books, Wellington, 1995); Robert Stephens "Social Services" in Brian Silverstone, Alan Bollard and Ralph Lattimore (eds) A Study of Economic Reform: The Case of New Zealand (Elsevier, Amsterdam, 1996) 451. 
expected to meet most of the cost of their social services". ${ }^{19}$ These were abandoned as not politically and administratively feasible, resulting in a "welfare mess". ${ }^{20}$

Despite supposedly achieving the correct incentive structures in the benefit and tax systems, numbers on income-tested benefits continued to grow, leading to a change in view as to reasons for accepting income-tested benefits. The problem was seen as a lack of individual motivation to seek work: the policy response was a mandatory welfare-to-work programme, where refusal of job interviews or employment offers could lead to sanctions on benefit receipt. Evaluations of this scheme have shown that there is no evidence of a long-term positive impact on training and employment outcomes, though many sponsors benefited through expansion of service delivery. ${ }^{21}$

\section{G Social and Economic Impacts}

Apart from a brief period in the mid-1990s, the economic and social outcomes are not really encouraging. Figure 1 shows that there were a couple of years where economic growth was significant, although that followed a couple of years of negative growth. If a Keynesian framework on macroeconomics is taken, then the recession of 1991-1993 is directly attributable to the significant reduction in aggregate demand brought about by the 1991 benefit cuts. This reduction in aggregate demand far outweighs any labour market incentive effects from the fall in the benefit replacement rate, ${ }^{22}$ resulting in an increase in unemployment and greater government expenditure. In the longer run, the new classical framework is more important, with the lower interest rates allowing a fall in the real exchange rate, improving international competitiveness, economic growth and lower unemployment were achieved, with a reduced balance of payment deficit and a budget surplus.

It was in the area of social outcomes that most objections to the National Government's policies were voiced. Critics argued that the social reforms had led to widespread hardship, with low income households requiring food parcels to survive, or shifting to overcrowded accommodation or to rural areas to lower housing costs. The claim was that there were short-term consequences on health and standards of living, and long-term impacts on educational attainment, child development and future economic growth potential. Proponents argued that while there were short-term transition effects,

19 Ruth Richardson "Statement by the Minister of Finance" in James (Jim) Bolger, Ruth Richardson and William (Bill) Birch Economic and Social Initiative (House of Representatives, Wellington, 1990).

20 Susan St John and Anne Heynes "The Welfare Mess" in University of Auckland Department of Economics Policy Discussion Paper No 15 (Auckland, 1994).

21 Department of Work and Income An Evaluation of the Expanded Community Taskforce Programme (Department of Work and Income, Wellington, 1999).

22 In 1986, Roger Douglas had also lowered the benefit replacement rate in order to give an incentive to move into the labour force, but did so by increasing the returns from work via a guaranteed minimum family income and the provision of the family support tax credit to low income workers. 
the improved economic performance, reduced dependency on the state, better work incentives, greater hospital efficiency and higher tertiary participation rates all indicate effective policy changes. ${ }^{23}$

Figure 4 shows trends in income inequality and poverty between 1984 and $1998 .{ }^{24}$ Hills claimed that New Zealand had the largest increase in inequality in the OECD. ${ }^{25}$ Much of the widening in household disposable income occurred during the 1980s, and at the top end of the scale as a result of increases in higher salaries and lower top tax rates, with increased unemployment having a small effect at the bottom end. The benefit cuts were the dominant cause of the next increase in inequality to 1993 , with the reductions in unemployment since then offsetting the impacts of greater earnings inequality.

Using a focus group method for establishing a poverty line, Stephens and Waldegrave show that updating the 1993 poverty line estimate by the consumer price index (an absolute poverty measure) results in a substantial increase in the incidence of poverty until 1994, and an equally rapid decline since then. ${ }^{26}$ The largest increase in poverty is for families with dependent children, especially those brought up in sole parent situations. However, using a relative method of updating the 1993 poverty measure (based on 60 per cent of median household disposable equivalent income), the incidence of poverty fluctuates and actually fell in 1992. A decomposition of the results shows a substantial fall in poverty among the elderly - median income fell substantially at this stage while nominal pension levels were maintained. The reverse situation appeared in 1998 when the incidence of poverty, predominantly for the elderly, jumped after a small cut in the real level of the pension. The impact of higher housing costs for state and private tenants on poverty is demonstrated by the divergence between the before- and after-housing costs poverty measures.

Other social indicators show mixed results. The Ministry of Social Development shows increased post-compulsory education retention rates despite the fee increases, better employment outcomes and improving trends in statistics such as cigarette smoking, life expectancy, road fatalities and workplace accidents. ${ }^{27}$ However, Te Puni Kokiri (The Ministry of Maori Development) highlights the large disparity in social and economic outcomes between Maori and

23 See generally Robert Stephens "Social Services" in Brian Silverstone, Alan Bollard and Ralph Lattimore (eds) A Study of Economic Reform: The Case of New Zealand (Elsevier, Amsterdam, 1996) 451.

24 Data prior to 1984 is not available. Since 1998, the Household Economic Survey (the data source for these graphs) has been triennial. However the method of collating the 2001 data makes the results incompatible with prior years.

25 John Hills Inquiry into Income and Wealth (Joseph Rowntree Foundation, New York, 1995).

26 Robert Stephens, Charles Waldegrave and Paul Frater "Measuring Poverty in New Zealand" (1995) 5 Social Policy Journal of New Zealand 88; Robert Stephens and Charles Waldegrave "The Effectiveness of the Transfer and Tax System in Reducing Poverty in 1998" (2001) 16 Social Policy Journal of New Zealand 77.

27 Ministry of Social Development The Social Report (Ministry of Social Development, Wellington, 2001). 
non-Maori, ${ }^{28}$ and Asher reports on the significance of child poverty on worsening health outcomes for many children. ${ }^{29}$ Blaiklock and colleagues indicate the vulnerability of children during the period of reform, and the initial lack of monitoring on the adverse impact on children's outcomes, though they do acknowledge an increased provision of social services targeted to those in greatest need since the mid-1990s. ${ }^{30}$

Equally, the efficiency gains from managed competition never materialised. Fiske and Ladd report that devolution and dezoning of schools resulted in substantial wasteful competition, whiteflight to "better schools", increased inequities between schools, no discernible improvement in educational achievement, but some greater diversity of school offerings. ${ }^{31}$ In health care, efficiency gains of roughly five per cent rather than the anticipated 20-30 per cent resulted in underfunding of hospitals, greater waiting lists, while the contracting out of outputs prevented flexibility of resource use. Incumbent monopoly positions from the presence of sunk costs meant that competition was largely restricted to elective surgery and long-term care. ${ }^{32}$ Some innovative social service delivery agency developed providing new and improved range of services to Maori and Pacific people, but most welfare agencies resented being accountable to the government for all of their output when only a fraction of their funding came from that source, and having service delivery tied to a contractual arrangement rather than responding flexibly on the basis of need. ${ }^{33}$

\section{H Social Development - Helen Clark and Labour Post-1999}

The election of the Labour/Alliance coalition Government in 1999 signalled an era when efficiency and equity concerns would be integrated. The initial policy responses of returning pension levels to 65 per cent of average earnings, returning to income-related rents for state housing, freezing tertiary fees and removing competition between health care and social service delivery providers and returning accident compensation to a state monopoly, showed both a commitment to social justice and a rejection of the competitive model for services provided by the State. Recent

28 Te Puni Kokiri Progress Towards Closing Social and Economic Gaps between Maori and non-Maori: A Report to the Minister of Maori Affairs (Te Puni Kokiri, Wellington, 2000).

29 Innes Asher, Dee Parks and Caroline Dakin "Poverty, Primary Care, and Child and Youth Health" in Child Poverty Action Group Backgrounder 20 (Child Poverty Action Group, Auckland, 2002).

30 Alison Blaiklock "When the Invisible Hand Rocks the Cradle: New Zealand Children in a Time of Change" Innocenti Working Paper No 93 (UNICEF Innocenti Research Centre, Florence, 2002).

31 Edward Fiske and Helen Ladd When Schools Compete: A Cautionary Tale (Brookings Institution Press, Washington DC, 2000).

32 Toni Ashton "The Health Reforms: To Market and Back?" in Jonathan Boston, Paul Dalziel and Susan St John (eds) Redesigning the Welfare State in New Zealand (Oxford University Press, Auckland, 1999) 134.

33 John R Martin "Contracting and Accountability" in Jonathan Boston (ed) The State Under Contract (Bridget Williams Books, Wellington, 1995) 36-55. 
work seems to have concentrated on developing holistic and inter-agency coordinated strategies to overcome the social problems, rather than specific policy developments.

A combination of favourable climatic conditions, high commodity prices and a favourable real exchange rate led to rural economic growth, and did not threaten inflation targets. Thus New Zealand could go against the OECD economic recession, with improvements in the balance of payments and budget surplus.

\section{CONCLUSIONS}

The two decades of economic and social reform have moved New Zealand from a heavily regulated and insular economy to one, by OECD standards, that is open and subject to market forces for the allocation of resources. Contrary to the predictions of liberal economic theory, the outcomes have been far from spectacular: modest economic growth, increasing income inequality and prevalence of poverty. Not all outcomes are pessimistic - unemployment, after initially increasing, is now at modest levels, the balance of payments deficit has improved and the government budget is in surplus.

The economic fundamentals should allow for sustained growth. However, this potted history has shown the importance of getting the real exchange rate correct, and that should become the main target of monetary policy, rather than inflation. The other lesson from history is to ensure that adverse effects from policy change are offset by social policy instruments such as the need for retraining and skilling after the programmes of corporatisation and trade liberalisation.

Whilst ACC started life at variance with traditional social policy and administrative arrangements, the subsequent changes to ACC have been more in line with the overall direction of policy reform than its origins. The shift in general social policy to user pays, cut backs in the universality of the scheme and the level of benefits, privatisation, the development of managed competition and the delivery of services under contractual arrangements to government funding organisations all have their counterparts in legislative and operative changes for the Accident Compensation scheme. 
Figure 1 Trends in Economic Growth, Inflation and Unemployment 19602002

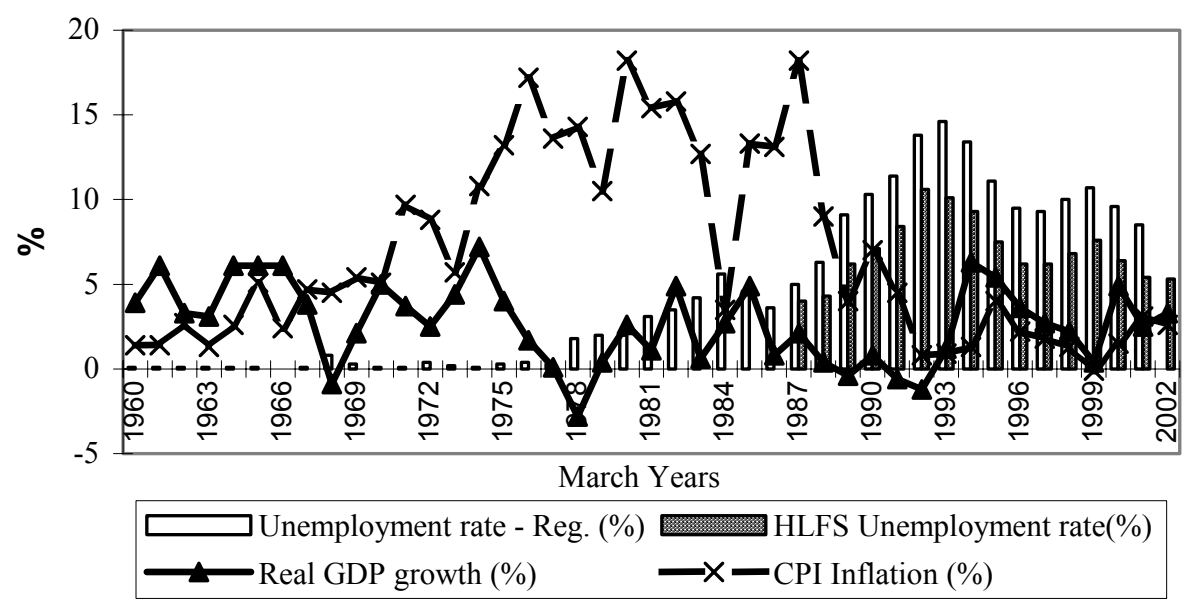

Source: Household Economic Survey

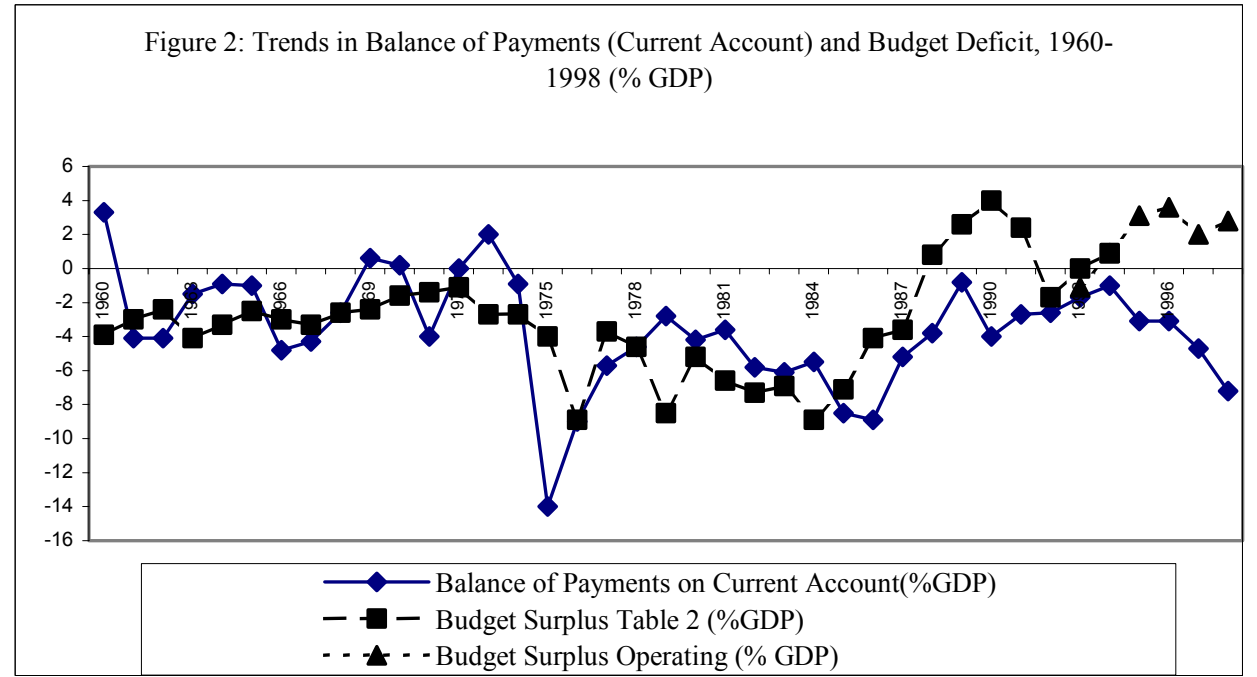

Source: Household Economic Survey 


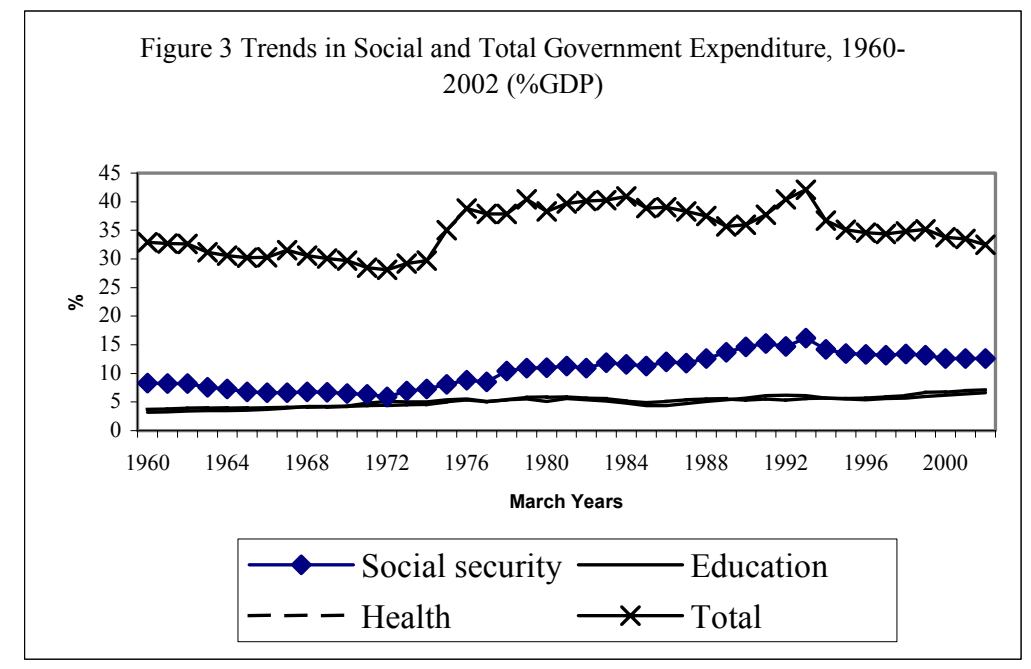

Source: Household Economic Survey

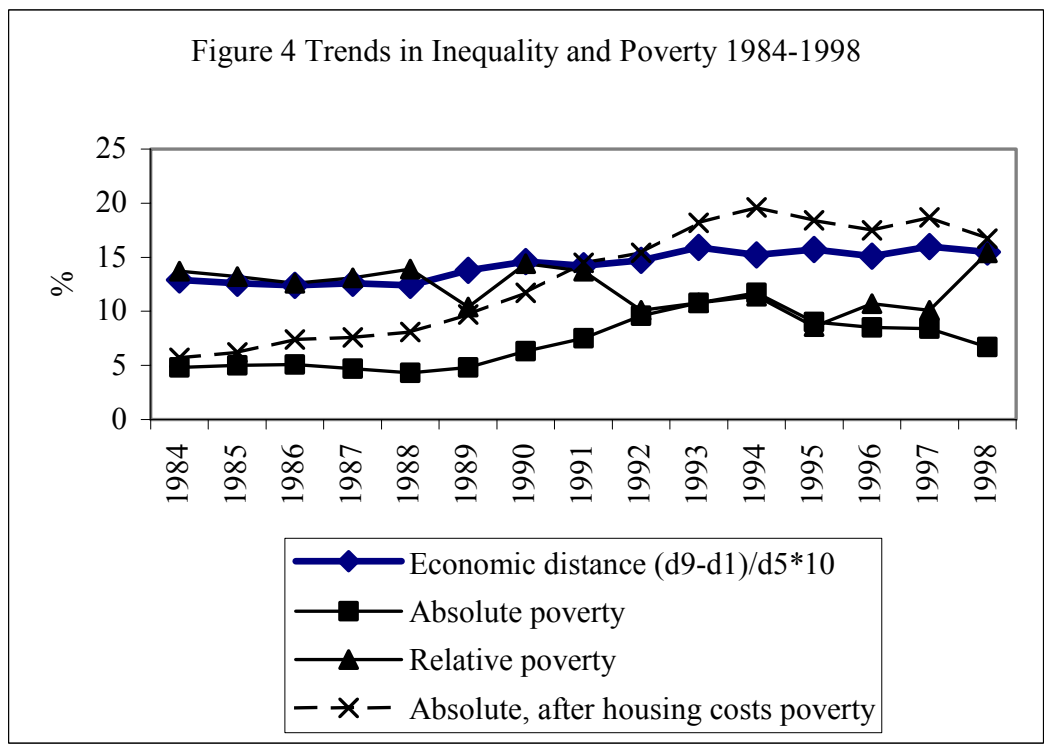

Source: Household Economic Survey 